Article

\title{
Insect Communities Associated with Siam Weed: Evaluation after Three Decades of Cecidochares connexa Release as Biocontrol Agent
}

\author{
Damayanti Buchori ${ }^{1,2} \oplus$, Akhmad Rizali ${ }^{3, * \mathbb{C}}$, Luna Lukvitasari ${ }^{1}$ and Hermanu Triwidodo ${ }^{1}$ \\ 1 Department of Plant Protection, Faculty of Agriculture, IPB University, Bogor 16680, Indonesia; \\ damayanti@apps.ipb.ac.id (D.B.); luna_lukvitasari@apps.ipb.ac.id (L.L.); hermanutr@apps.ipb.ac.id (H.T.) \\ 2 Center for Transdisciplinary and Sustainability Sciences, IPB University, Bogor 16129, Indonesia \\ 3 Department of Plant Pests and Diseases, Faculty of Agriculture, University of Brawijaya, \\ Malang 65145, Indonesia \\ * Correspondence: arizali@ub.ac.id; Tel./Fax: +62-341-575843
}

Received: 24 July 2020; Accepted: 4 September 2020; Published: 7 September 2020

\begin{abstract}
Chromolaena odorata is well known as an invasive weed, and its existence in agricultural habitats causes an undesirable effect on crop plants. The invasion of $C$. odorata alters local biodiversity and shapes the new trophic interaction with local herbivores and other insects. This research was conducted to study the insect communities associated with $C$. odorata and evaluate the success of the release of Cecidochares connexa, the natural enemy of $C$. odorata. Field research was conducted in two different geographical regions in Bogor Regency (Java) and South Lampung Regency (Sumatera), Indonesia. In each region, we selected five villages that have two land-use types (oil palm plantations and open area) and contain a high population of $C$. odorata. Observation of insects and natural enemies of $C$. odorata was conducted in each land-use type using two methods: suction sampling and gall collection, which were performed in 30 plants as sampling units. In total, we found 255 species of insects associated with $C$. odorata. The difference of region affected the abundance of insects but not their species richness. The species composition of insects showed difference between regions as well as between land-use types. There was a positive correlation between elevation and species richness of insects. In addition, the population of $C$. connexa (gall numbers) was significantly affected by regions and was found to be higher in Bogor and Lampung. The same pattern also was shown for its parasitoids (based on parasitized galls). We found a negative relationship between the number as well as parasitize galls and elevation. In conclusion, the presence of $C$. odorata, as well as its natural enemies, shape the new trophic interaction with local insects, and as consequence, its introduced natural enemies may not be effective to control the population of $C$. odorata.
\end{abstract}

Keywords: Chromolaena odorata; open area; oil palm; parasitoid wasp

\section{Introduction}

The Siam weed, Chromolaena odorata, is a well-known exotic invasive species which originates from tropical America and has become widespread in Asia. Based on herbarium record, C. odorata was first reported in India in 1872 [1,2] and then spread to Sumatera, Indonesia in 1934 [3]. The invasion of Siam weed in a new region can cause biotic homogenization and its existence in an agricultural area can be destructive to crop plants due to nutrient competition [4]. The replacement of native plants by C. odorata is due to the effect of allelopathy [5] and the ability of this invasive weed to change the soil quality [6] as well as the soil microbial community [7]. Therefore, the control of C. odorata, especially in agricultural areas, is very crucial to prevent the negative effect on crop plants and avoid economic loss. In Indonesia, the common methods of controlling C. odorata in plantations include a mechanical 
approach (e.g., uprooting the weeds), slashing, and chemical control using herbicides [3]. However, these methods have not been reported successful due to the ability of $C$. odorata to recover rapidly. Tjitrosemito [3] found that Siam weed grows vegetatively during the wet season, flowers and sets a high number of fruits at the end of the wet season, and senesces during the dry season.

Considering the characteristics of $C$. odorata, the use of biological control agents that attack leaves, branches, and flowers is seen as a promising approach to control this weed. As a classical biological control approach, the natural enemies from the native range of Siam weed are introduced to the new invasion area. This method is considered to have several advantages, such as effective control of the weed population by way of hindering its ability to establish and spread to other areas, and also the consideration of control cost, which is lower than herbicide application [8-10]. In Indonesia, several natural enemies have been introduced to control Siam weed, e.g., Pareuchaetes pseudoinsulata Rego Baros (Lepidoptera: Arctiidae) from Guam in 1992 in North Sumatra. Yet, the introduction of P. pseudoinsulata was only able to suppress the population of Siam weed in North Sumatra and was not successful in other areas, such as Java [11]. Then in 1993, a gall fly, Cecidochares connexa Macquart (Diptera: Tephritidae) was introduced from Columbia into quarantine at the Indonesian Oil Palm Research Institute in North Sumatra and was released in 1995 in West Java [12,13]. A two years' post release evaluation of $C$. connexa indicated that the population of $C$. odorata went down to $37.2 \%$ and the production of seeded fruits decreased by about $50 \%$ in one season [3]. However, the effectiveness of C. connexa can be reduced due to parasitism and predation [1]. McFadyen et al. [13] reported that five years after the first releases at the sites, parasitism and predation can exceed $50 \%$. Recent research in Java also reported a new complex interaction between $C$. connexa and local insects that may reduce the effectiveness of $C$. connexa to control $C$. odorata [14]. This is perhaps one of the reasons why C. odorata is still a problem in agricultural areas, especially plantations.

A biological control program of invasive weeds can be unsuccessful if the natural enemies fail to adapt to the new habitat, and are therefore less effective than in their area of origin. In addition, natural enemies with a broad host range can cause a non-target impact through physical and functional replacement of local species [15]. The presence of a new species in a new habitat also alters the community structure and trophic level dynamics, and may affect the stability of ecosystems [16]. Thus, the introduction of exotic species should be reviewed by considering the conservation perspective. If no alternative approach is available, the introduction of biological control agents must go through a rigorous screening process to determine its potential effectiveness against the target weed and impact on non-target organism. In addition, monitoring the new region is necessary to avoid negative impacts on local biodiversity [17]. With long-term monitoring, biodiversity degradation or native species extinction in an ecosystem will be detected especially in the region of the introduced natural enemies $[18,19]$.

The objectives of this study were to assess the insect communities associated with C. odorata and to evaluate, three decades post-release, the population levels of $C$. connexa in Indonesia. The research is part of a monitoring and evaluation study to investigate the factors affecting the decrease of biological control agent effectivity to control invasive weeds. The results can be used as a recommendation for classical biological control strategy in Indonesia and for biodiversity conservation efforts especially related to the management of invasive species in tropical regions. This is to avoid the reluctance of government and other stakeholders to pursue weed biological control, due to poor perceptions of biological control [10].

\section{Materials and Methods}

\subsection{Research Site and Plot Selection}

This research was conducted in two geographical regions in West Java (Java Island) and Lampung (Sumatera) to compare the diversity in different islands. In West Java, we selected the research area in Bogor Regency, which was the historical release site for C. connexa, whereas in Lampung, we selected a 
research area in South Lampung Regency, as a representative area in which C. connexa has never been released, which is geographically isolated and far from the release sites both in Java and Sumatera (North Sumatera). In each research area, five villages were chosen that fulfill the existence of two land-use types, i.e., oil palm plantations and open area, and have a large population of $C$. odorata (Figure 1). Open areas were defined as areas without trees, not being cultivated by crops and dominated by grass and bushes. We preferred to choose oil palm plantation due to this weed causing serious problems in plantations, and especially oil palm ones. In addition, this weed is also suitable to habitats with less tree cover. In each land-use type, we selected 30 plants of $C$. odorata as sampling units for the observation and sampling of insects.

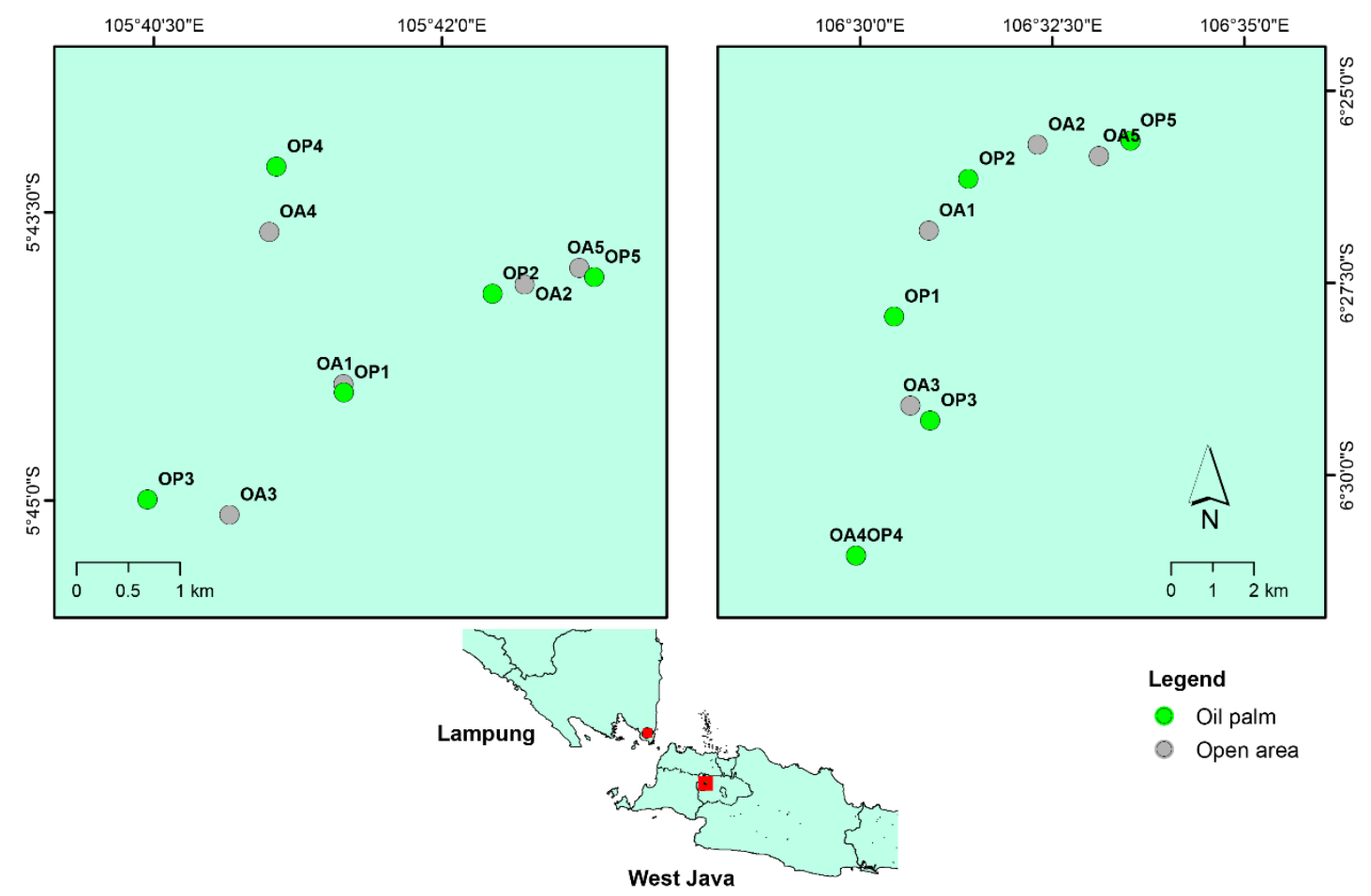

Figure 1. Map of the research area for insect observation in C. odorata in Bogor Regency, West Java (right) and South Lampung Regency, Lampung (left). The letters followed by numbers indicate site codes. The letters indicate land-use type: $\mathrm{OA}=$ open area, $\mathrm{OP}=$ oil palm; and the numbers (1-5) indicate villages as replications. Villages of Bogor Regency: 1 = Argapura, 2 = Bangun Jaya, 3 = Cantik Manik, $4=$ Mekar Jaya, and 5 = Rengasjajar. Villages of South Lampung Regency: $1=$ Klaten, 2 = Ngandri, $3=$ Pasuruan, $4=$ Ruang Tengah, and $5=$ Tetaan.

\subsection{Sampling and Identification of Insects}

Field research was conducted during the rainy season from November 2018 to January 2019. We conducted two different sampling methods to cover insect diversity associated with $C$. odorata and the population of its natural enemy (C. connexa) as well as other insects associated with $C$. connexa. The sampling of insects in C. odorata was conducted using the suction method with a FARMCOP. The FARMCOP is a suction sampler for insects that was developed by Carino, et al. [20] and is commonly used to sample brown planthoppers in the rice fields. Before sampling, we randomly selected 30 plants with similar size and architecture. Each plant was then covered by a net and all insects were sucked for $5 \mathrm{~min}$. The collected specimens were then stored in plastic vials containing $70 \%$ alcohol for later identification in the laboratory. The sampling by the FARMCOP was conducted in the morning between $7 \mathrm{AM}$ and $9 \mathrm{AM}$ and with sunny weather.

For sampling of the natural enemy of $C$. odorata, we observed and collected the galls in $C$. odorata. The galls are a symptom of the abnormal development of stems or stalks due to attacks by $C$. connexa. In each land-use type, we randomly selected 30 plants with similar size and architecture that were not 
the same plants that were sampled using the FARMCOP. From each plant, all galls were collected by cutting the stalks and taken to the laboratory. Each gall was put in a plastic container (diameter $=6 \mathrm{~cm}$, height $=10 \mathrm{~cm}$ ) and observed for one month. Observations were done for the emergence of parasitoids or other insects. Toward the end of the observation period, each gall was dissected, and the number of gall flies inside the galls were counted.

Samples of insects collected using both methods was initially sorted to the order level and later identified to the family and genera level using several relevant taxonomic literatures, e.g., Borror, et al. [21], CSIRO [22], McAlpine [23], Goulet and Huber [24], and Bolton [25]. All specimens were then determined to the morphospecies level based on their morphological characteristic, and if possible were identified to species level by comparing with voucher specimens at the Laboratory of Insects and other Arthropod Taxonomy, Indonesian Institute of Science.

\subsection{Data Analysis}

Species accumulation curves were used to compare insect species richness between different regions and land-use types based on plant numbers of $C$. odorat $a$ as a sampling unit. To assess the completeness of sampling, the Chao estimator [26] was calculated for each region and each land-use type. Analysis of variance (ANOVA) was used to compare the species richness and abundance of insects between different regions and land-use types. The relationship between the species richness and abundance of insects and elevation was analyzed using regression analysis. Data of insect abundance were transformed to $\log (x+1)$ to achieve normal distribution. Differences in insect community structure were quantified using the Bray-Curtis index for dissimilarity based on species abundance. The dissimilarity matrix was then reduced to a two-dimensional ordination using non-metric multidimensional scaling (NMDS) [27]. The effects of region and land-use type on species composition of insects were assessed by analyses of similarity (ANOSIM) [28].

To evaluate the release of $C$. connexa to $C$. odorata, ANOVA was used to compare the gall numbers and parasitized galls between regions and land-use types. Regression analysis was then used to analyze the relationship between gall numbers as well as parasitized galls and elevation. Data of gall numbers and parasitized galls were approximately normal following $\log (x+1)$ transformation. All analyses were performed using R statistical software [29], utilized the BiodiversityR package to calculate the Chao species estimator, created the species accumulation curve [30], used the ggplot2 package to visualize the boxplot and regression plot [31], and used the vegan package for analysis of NMDS and ANOSIM [32].

\section{Results}

\subsection{Insect Diversity Associated with C. odorata}

In total, we found 255 species and 13,325 individuals of insects associated with C. odorata, including 181 species and 10,944 individuals from Bogor and 161 species and 2381 individuals from Lampung (Table 1). The most abundance of insects (91.4\%) were Aphis gossypii (Hemiptera: Aphididae) with 10,168 individuals (76.3\% of total individuals) and ants (Hymenoptera: Formicidae) with 2005 individuals (15.1\%) with Dolichoderus sp as the most dominant species (1091 individuals). The most species-rich were hymenopteran, which were found with 124 species within the total area $(48.6 \%$ from total species). 
Table 1. Insects diversity associated with C. odorata collected by vacuum methods both in Bogor and Lampung. S: species richness, N: number of individuals.

\begin{tabular}{|c|c|c|c|c|c|c|c|c|c|c|c|}
\hline \multirow{3}{*}{ No } & \multirow{3}{*}{ Order } & \multicolumn{4}{|c|}{ Bogor } & \multicolumn{4}{|c|}{ Lampung } & \multicolumn{2}{|c|}{ Entire Area } \\
\hline & & \multicolumn{2}{|c|}{ Open Area } & \multicolumn{2}{|c|}{ Oil Palm } & \multicolumn{2}{|c|}{ Open Area } & \multicolumn{2}{|c|}{ Oil Palm } & \multirow[b]{2}{*}{$S$} & \multirow[b]{2}{*}{$\mathbf{N}$} \\
\hline & & $\mathrm{S}$ & $\mathbf{N}$ & $S$ & $\mathbf{N}$ & $S$ & $\mathbf{N}$ & $\mathrm{S}$ & $\mathbf{N}$ & & \\
\hline 1. & Araneae & 13 & 31 & 15 & 41 & 11 & 15 & 9 & 13 & 25 & 100 \\
\hline 2. & Blattodea & 0 & 0 & 1 & 1 & 0 & 0 & 1 & 1 & 2 & 2 \\
\hline 3. & Coleoptera & 14 & 29 & 9 & 17 & 6 & 16 & 5 & 6 & 25 & 68 \\
\hline 4. & Diptera & 16 & 40 & 24 & 118 & 13 & 69 & 9 & 48 & 30 & 275 \\
\hline 5. & Hemiptera & 14 & 2352 & 13 & 6755 & 13 & 162 & 12 & 1193 & 32 & 10,462 \\
\hline 6. & Hymenoptera & 45 & 1159 & 61 & 299 & 65 & 357 & 50 & 450 & 124 & 2265 \\
\hline 7. & Lepidoptera & 2 & 8 & 0 & 0 & 2 & 2 & 1 & 1 & 3 & 11 \\
\hline 8. & Mantodea & 2 & 7 & 3 & 33 & 3 & 10 & 1 & 2 & 3 & 52 \\
\hline 9. & Odonata & 0 & 0 & 0 & 0 & 1 & 1 & 0 & 0 & 1 & 1 \\
\hline 10. & Orthoptera & 8 & 22 & 7 & 28 & 5 & 12 & 5 & 19 & 9 & 81 \\
\hline \multirow[t]{2}{*}{11.} & Thysanoptera & 0 & 0 & 1 & 4 & 1 & 3 & 1 & 1 & 1 & 8 \\
\hline & & & & & & & & & Total & 255 & 13,325 \\
\hline
\end{tabular}

We found that Bogor had a higher number of insect species (182 species, 64.6\% of the Chao estimated species) than Lampung (162 species, $57.8 \%$ of the Chao estimated species) (Figure 2a). Based on land-use type, the oil palm plantations of Bogor had the highest insect diversity (135 species, $55.0 \%$ of the Chao estimated species), whereas the lowest diversity was found in the oil palm plantations of Lampung (95 species, 56.4\% of the Chao estimated species) (Figure $2 \mathrm{~b}$ ).
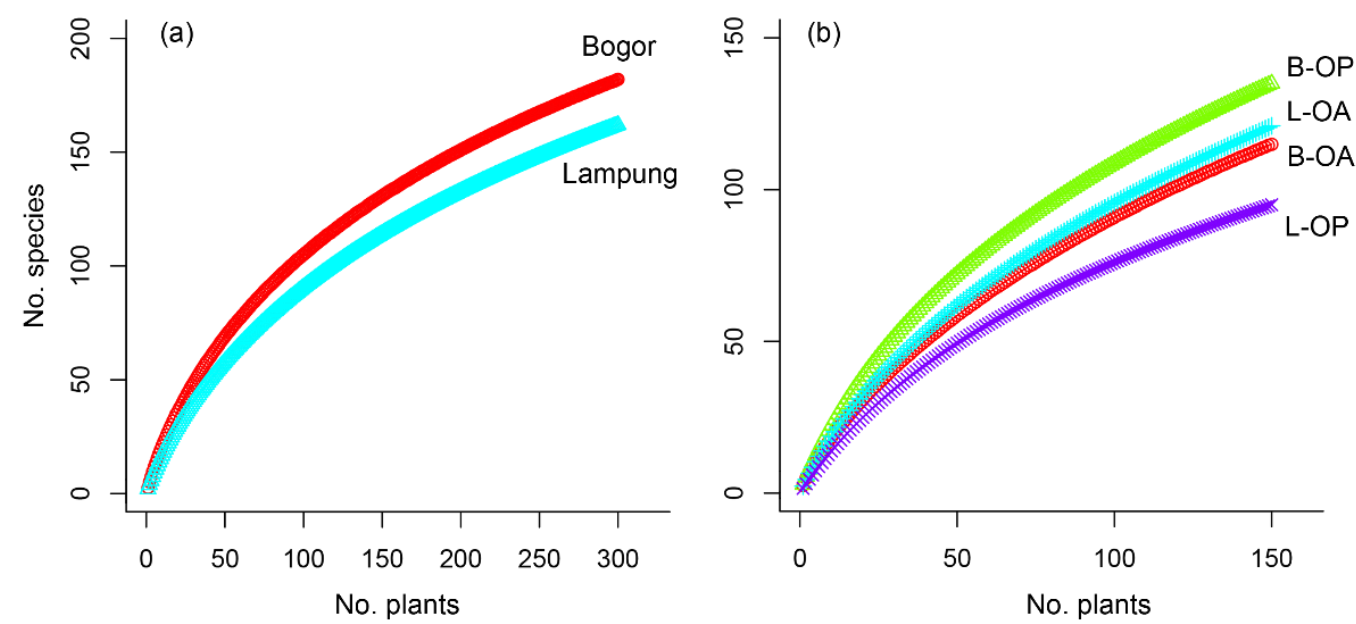

Figure 2. Species accumulation curve of insect diversity based on the number of C. odorata plants. (a) Insect diversity between Bogor and Lampung, (b) insect diversity between different land-use types in Bogor and Lampung. B-OP = oil palm in Bogor, B-OA = open area in Bogor, L-OP = oil palm in Lampung, L-OA = open area in Lampung.

Based on ANOVA, we found different abundances of insects between Bogor and Lampung $\left(F_{1,17}=9.596, p=0.007\right)$, but not for species richness $\left(F_{1,17}=0.754, p=0.397\right)$ (Figure 3a,b). Land-use type did not affect the diversity of insects in C. odorata $(p>0.05)$. In addition, we found a positive relationship between elevation and species richness of insects $\left(R^{2}=0.35, p=0.006\right)$ and no correlation with insect abundance $\left(\mathrm{R}^{2}=0.04, p=0.657\right)$ (Figure 3c,d). 

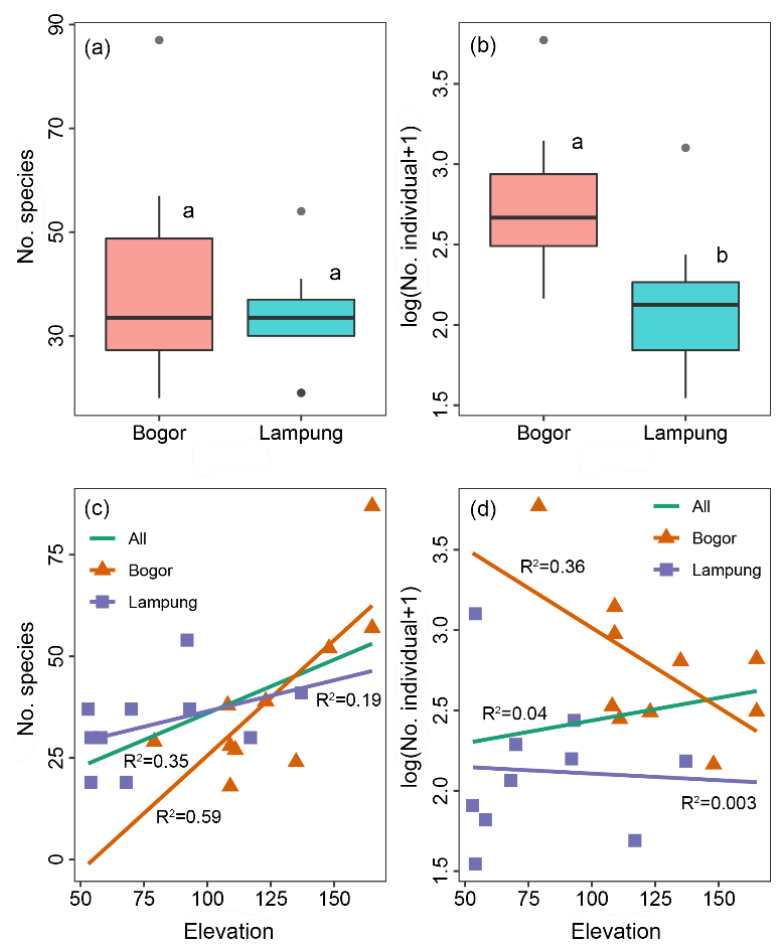

Figure 3. Difference of (a) species richness and (b) individual of insects between Bogor and Lampung and the relationship between elevation ( $\mathrm{m}$ above sea level) and (c) species number and (d) individual insects. Data of insect individual were transformed to $\log (x+1)$ to achieve normal distribution. Boxplots with different letters was significantly different at $p<0.05$ according to Tukey's test.

Based on ANOSIM, we found that the similarity of insect species composition was significantly different between regions ( $R=0.39, p=0.002)$ and as visualized in the ordination results of the NMDS analysis, also separated between Bogor and Lampung (Figure 4a). By contrast, the species composition of insects between land-use types did not differ $(R=-0.05, p=0.718)$, indicated by the overlap of plot groups within a region (Figure 4 b).
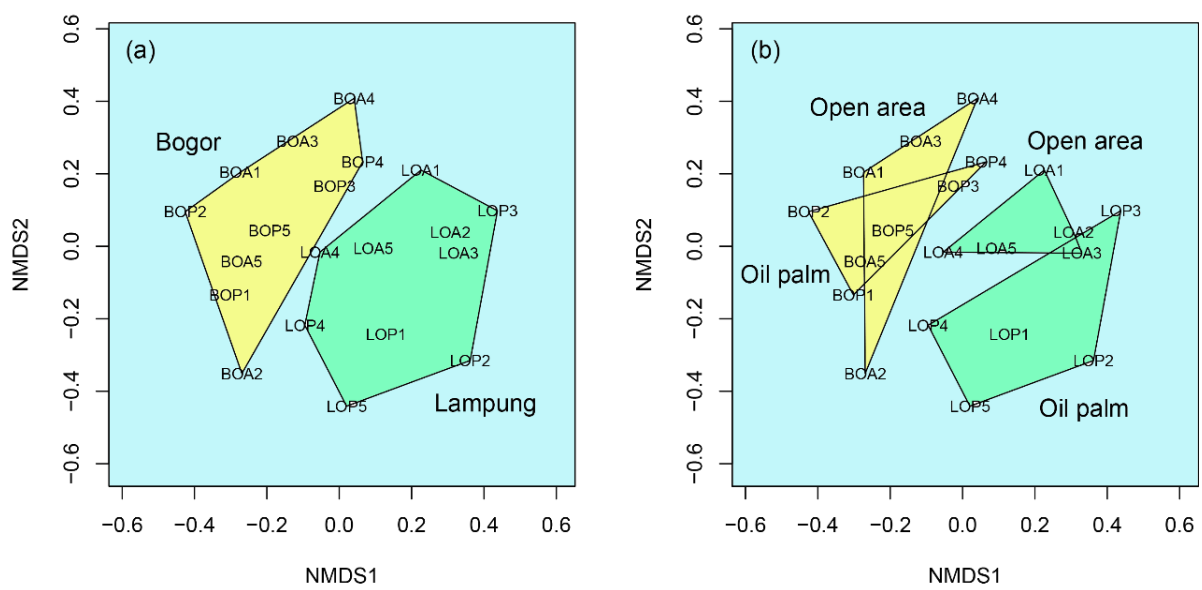

Figure 4. Two-dimensional non-metric multidimensional scaling ordination (NMDS) of insect species composition by $\mathrm{C}$. odorata based on a Bray-Curtis dissimilarity index. Plots are grouped by (a) different regions and (b) land-use types. The letters followed by the number indicated plot codes. The first letter indicates the region: $\mathrm{B}=$ Bogor, $\mathrm{L}=$ Lampung; the second and third letters are land-use type: $\mathrm{OA}=$ open area $\mathrm{OP}=$ oil palm; and the numbers (1-5) are replications. 


\subsection{Evaluation of the Release of C. connexa as the Natural Enemy of C. odorata}

The evaluation of the release of C. connexa was measured based on the number of galls and the parasitized galls in C. odorata that were found both in Bogor and Lampung. In total, we found 2218 galls from all research areas. The number of galls varied and ranged from 0 to 109 galls per plant with an average of 3.69 galls per plant. The gall number in Lampung was significantly higher than in Bogor $\left(\mathrm{F}_{1,17}=7.787, p=0.013\right.$; Figure $\left.5 \mathrm{a}\right)$. The number of galls that were parasitized by parasitoids was also higher in Lampung than in Bogor $\left(\mathrm{F}_{1,17}=12.026, p=0.003\right.$; Figure $\left.5 \mathrm{~b}\right)$. There was a negative relationship between elevation and gall numbers $\left(\mathrm{R}^{2}=0.27, p=0.019\right.$; Figure $\left.5 c\right)$ as well as parasitized galls $\left(R^{2}=0.20, p=0.046\right.$; Figure $\left.5 d\right)$.
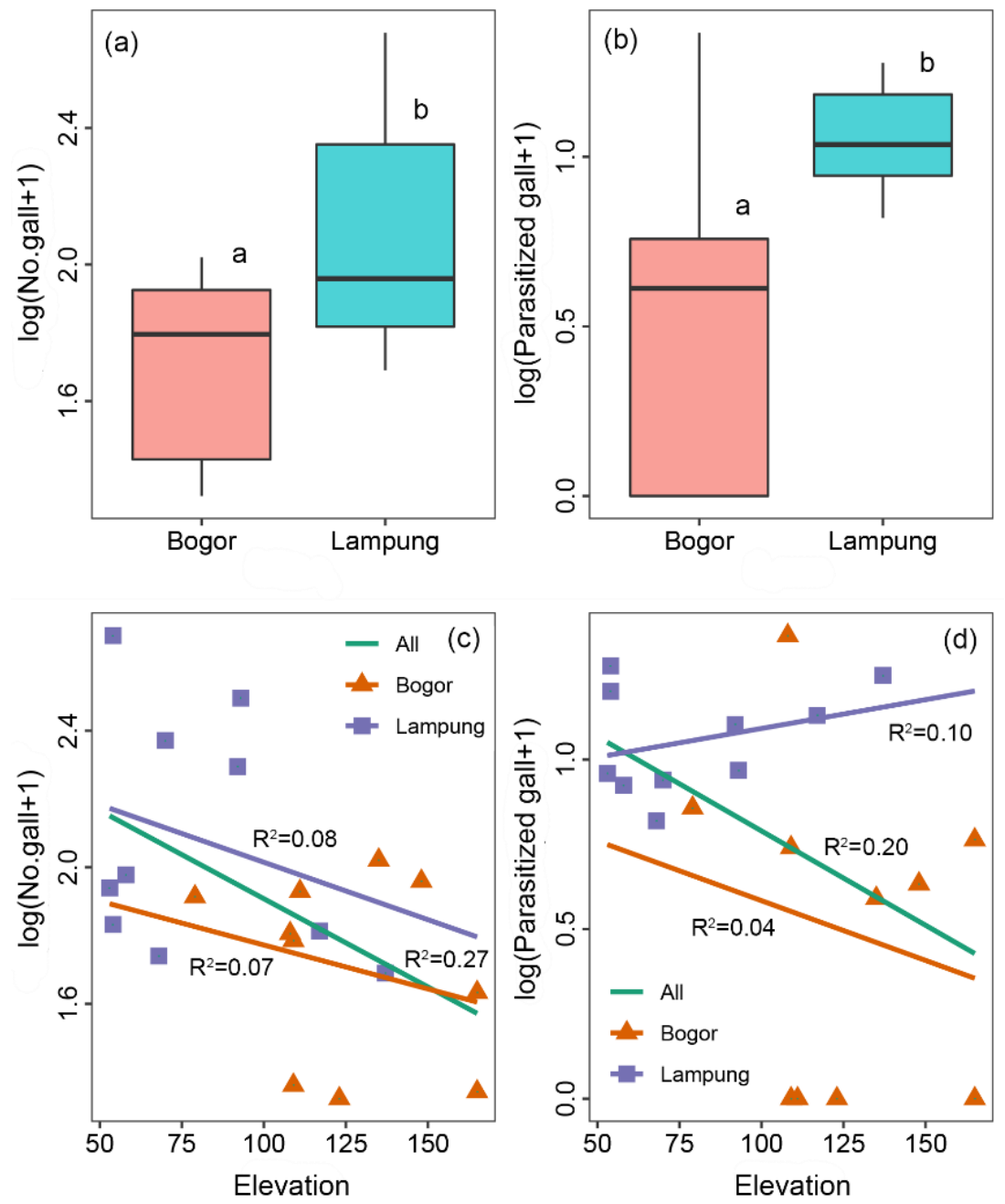

Figure 5. Difference of (a) gall numbers and (b) parasitized gall between Bogor and Lampung and the relationship between elevation ( $\mathrm{m}$ above sea level) and (c) gall numbers and (d) parasitized gall. Data were transformed to $\log (x+1)$ to achieve normal distribution. Boxplots with different letters are significantly different at $p<0.05$ according to Tukey's test.

Based on galls reared, C. odorata was found to be attacked by two gall flies species, i.e., C. connexa (introduced species) and Lonchaea sp (local species, Diptera: Lonchaeidae). Loncaea sp was only recorded in Lampung and with only five individuals from both open areas and oil palm plantations. In addition, we found eight families and 13 species of parasitoid wasps that emerged from the galls (Table 2). The species richness of parasitoid wasps was higher in Lampung (11 species) than in Bogor (four species). The most dominant parasitoid wasp was Quadrastichus sp (Eulophidae), recorded in all research areas. 
Table 2. Species richness and abundance of gall flies and associated parasitoid wasps that emerged from gall samples. $\mathrm{OA}=$ open area $\mathrm{OP}=$ oil palm plantation .

\begin{tabular}{|c|c|c|c|c|c|c|c|c|}
\hline \multirow{2}{*}{ No. } & \multirow{2}{*}{ Family } & \multirow{2}{*}{ Species } & \multicolumn{2}{|c|}{ Bogor } & \multicolumn{2}{|c|}{ Lampung } & \multirow{2}{*}{ Entire Area } & \multirow{2}{*}{ Role } \\
\hline & & & OA & OP & OA & OP & & \\
\hline \multicolumn{9}{|c|}{ DIPTERA } \\
\hline 1. & Tephritidae & $\begin{array}{c}\text { Cecidochares } \\
\text { connexa }\end{array}$ & 13 & 36 & 194 & 227 & 470 & Gall fly \\
\hline 2. & \multicolumn{7}{|c|}{ HYMENOPTERA } & Gall fly \\
\hline 1. & Bethylidae & Bethylidae sp & & 1 & & & 1 & Parasitoid \\
\hline 2. & Braconidae & Braconidae sp1 & & & 3 & 7 & 10 & Parasitoid \\
\hline 3. & & Braconidae sp2 & & & 1 & 2 & 3 & Parasitoid \\
\hline 4. & Encyrtidae & Encyrtidae sp & & & 1 & & 1 & Parasitoid \\
\hline 5. & Figitidae & Eucoilinae sp1 & & & 1 & 1 & 2 & Parasitoid \\
\hline 6. & & Eucoilinae sp2 & & & 1 & & 1 & Parasitoid \\
\hline 7. & & Eucoilinae sp3 & & & 1 & & 1 & Parasitoid \\
\hline 8. & Eulophidae & Quadrastichus sp & 14 & 8 & 52 & 102 & 146 & Parasitoid \\
\hline 9. & Eupelmidae & Eupelmidae sp & & & & 1 & 1 & Parasitoid \\
\hline 10. & Eurytomidae & Eurytomidae sp1 & & & 1 & 3 & 4 & Parasitoid \\
\hline 11. & & Eurytomidae sp2 & & & 1 & & 1 & Parasitoid \\
\hline 12. & Pteromalidae & Pteromalidae sp1 & 2 & 1 & 1 & 4 & 8 & Parasitoid \\
\hline 13. & & Pteromalidae sp2 & & 1 & & & 1 & Parasitoid \\
\hline
\end{tabular}

\section{Discussion}

In the present study, we found a higher diversity of insects associated with $C$. odorata than in the native area of $C$. odorata. In Trinidad and other areas of the native range of $C$. odorata, 225 insects and mites were found associated with the weed [33]. Our results showed that $C$. connexa, the introduced natural enemy of $C$. odorata, still exists in Bogor Regency at the release site and even has dispersed to areas where it has never been released, such as South Lampung Regency. This indicates that $C$. connexa is well adapted and has established itself in the tropical region and can spread in a wide range of geographical areas, although its effectiveness to control the population of $C$. odorata is to be questioned due to parasitism and predation by local insects. In general, the parasitism and predation levels of C. connexa on C. odorata remained low, although in a certain conditions the parasitism reached $50 \%$ of a sample of 18 galls at one site [13]. C. connexa has been reported to be established easily from small founder populations, and once established, its population can rapidly build up and spread [12]. The population of C. connexa in South Lampung may come from North Sumatera as a release site in Sumatra [13]. Based on Desmier de Chenon et al.'s study [11], C. connexa can spread over $200 \mathrm{~km}$ within 5 years following release. However, the population in South Lampung may have also come from West Java, which is the closest distance from the release site although it is separated from it by the Sunda Strait.

One interesting finding is the new association that $C$. connexa has with local parasitoids, which may affect its effectiveness to control $C$. odorata. This finding suggests that this new association is a factor that needs to be taken into consideration for classical biological control in the future [34]. The most dominant parasitoid was Quadrastichus sp. This genus is known for plant gall wasp species, such as Quadrastichus erythrinae, the Erythrina gall wasp [35], and also as for parasitoids, such as Quadrastichus mendeli, a parasitoid of the eucalyptus gall wasp (Leptocybe invasa) [36]. In addition, C. odorata also has a new association with local gall fly species, Lonchaea sp [37] and A. gossypii. As the most abundant herbivore to be associated with $C$. odorata, aphids were found attacking the shoot tips. It appears there is a competition between C. connexa and A. gossypii due to the fact that the gall fly uses the shoot tips for laying eggs and the larvae develop within galls at the nodes of the plant. In this research, we did not investigate the effect of aphids on C. odorata as well as $C$. connexa. However, previous research by Watanabe, et al. [38] revealed that the parasitism of aphid, Macrosiphoniella yomogicola, significantly decreased the number of inflorescences of the mugwort (Artemisia montana). The presence of several 
herbivores may be effective to control C. odorata, which was also shown in the simultaneous occurrence between $C$. connexa and P. pseudoinsulata that significantly reduced the performance of $C$. odorata $[39,40]$.

The interaction of $C$. odorata with $C$. connexa, local herbivores, and other insects was affected by region and elevation, but not by land-use type. This is due to the ability of C. odorata to establish itself and become dominant in different land-use types in sunny and open areas (e.g., disturbed areas, grasslands, and plantations) while not being able to bloom under the shaded conditions of undisturbed forest [1]. Elevation was reported to affect the distribution of $C$. odorata. In its native range, $C$. odorata can grow from the coast to an elevation of 1000-1500 m asl [41] and in Asia, C. odorata can be found up to $1000 \mathrm{~m}$ asl [42]. The population density of C. connexa is also affected by elevation, and it can be more effectively controlled by $C$. odorata in lower elevations, especially in areas with a short dry season [13]. At higher elevations and cooler areas, the abundance of $C$. connexa is lower due to the fact that the population tends to build up slowly [1]. The same pattern was also shown for associated parasitoids-the parasitism of C. connexa becomes lower at higher elevations. By contrast, the species richness of insects associated with $C$. odorata tends to increase with increasing elevation. In general, the diversity of insects tends to increase with increasing elevation, though the maximum species richness occurs at intermediate elevations [43]. However, there is a complex interplay between local ecological interactions that determines the effect of elevation on the species richness of insects [44].

The interaction between $C$. odorata and local insect diversity as well as $C$. connexa with local parasitoids indicates a consequence of the presence of new species in a new habitat that may provide ecosystem services or disservices. As a host-specific herbivore $[13,45]$, the new interaction may impair the existence of $C$. connexa and cause the failure to control $C$. odorata $[17,46]$, as well as possibly support ecosystem disservices due to non-target impacts [47]. The results of this research showed the importance to understand the long-term effect of the introduction of natural enemies on their ability to control their target species [48]. This research revealed that introduced biological control agents encounter reduced effectiveness to control invasive weeds due to new interactions with local insects diversity (e.g., natural enemies).

\section{Conclusions}

Our research results revealed that the elevation and geographical area affect the insect communities associated with $C$. odorata as well as its natural enemy, C. connexa. We recorded a new association of local gall fly, Lonchaea sp., and A. gossypii (the most abundant herbivore) with the Siam weed. We also found a new association between $C$. connexa and 13 species of parasitoid wasps that are dominated by Quadrastichus sp. These results indicate that the release of introduced biological control agents of invasive weeds will have reduced effectiveness as a consequence of new associations with local insects. Thus, long-term studies to determine the effect of trophic interaction on biological control agents are needed to conserve the population and effectivity of biological control agents.

Author Contributions: Conceptualization, D.B., A.R., L.L., and H.T.; methodology, D.B., and H.T.; formal analysis, A.R. and L.L.; writing - original draft preparation, D.B., A.R., and L.L.; writing一review and editing, D.B., A.R., and L.L. All authors have read and agreed to the published version of the manuscript.

Funding: This research was funded by the Directorate General of Higher Education, Ministry of Education and Culture, the Republic of Indonesia through the grant program of Fundamental Research, the year 2020.

Acknowledgments: We thank Purnama Hidayat and Pudjianto who provided comments and inputs during research design.

Conflicts of Interest: The authors declare no conflict of interest. 


\section{References}

1. Zachariades, C.; Day, M.; Muniappan, R.; Reddy, G.V.P. Chromolaena odorata (L.) King and Robinson (Asteraceae). In Biological Control of Tropical Weeds Using Arthropods; Muniappan, R., Reddy, G.V.P., Raman, A., Eds.; Cambridge University Press: Cambridge, UK, 2009; pp. 130-162.

2. Gautier, L. Taxonomy and distribution of a tropical weed, Chromolaena odorata (L.) R. King and H. Robinson. Candollea 1992, 47, 645-662.

3. Tjitrosemito, S. The establishment of Procecidocares connexa in West Java, Indonesia: A biological control agent of Chromolaena odorata. Biotropia 1999, 12, 19-24.

4. Paini, D.R.; Sheppard, A.W.; Cook, D.C.; Barro, P.J.D.; Worner, S.P.; Thomas, M.B. Global threat to agriculture from invasive species. Proc. Natl. Acad. Sci. USA 2016, 113, 7575-7579. [CrossRef] [PubMed]

5. Hu, G.; Zhang, Z. Allelopathic effects of Chromolaena odorata on native and non-native invasive herbs. J. Food Agric. Environ. 2013, 11, 878-882.

6. Mandal, G.; Joshi, S.P. Invasion establishment and habitat suitability of Chromolaena odorata (L.) King and Robinson over time and space in the western Himalayan forests of India. J. Asia-Pac. Biodivers. 2014, 7, 391-400. [CrossRef]

7. Mangla, S.; Callaway, R.M. Exotic invasive plant accumulates native soil pathogens which inhibit native plants. J. Ecol. 2008, 96, 58-67. [CrossRef]

8. Schoonhoven, L.M.; Jermy, T.; van Loon, J.J.A. Insect-Plant Biology: From Physiology to Evolution; Chapman \& Hall: London, UK, 1996.

9. Van Driesche, R.G.; Carruthers, R.I.; Center, T.; Hoddle, M.S.; Hough-Goldstein, J.; Morin, L.; Smith, L.; Wagner, D.L.; Blossey, B.; Brancatini, V.; et al. Classical biological control for the protection of natural ecosystems. Biol. Control 2010, 54, S2-S33. [CrossRef]

10. Day, M.; Witt, A.; Winston, R. Weed biological control in low- and middle-income countries. Curr. Opin. Insect Sci. 2020, 38, 92-98. [CrossRef]

11. Desmier de Chenon, R.; Sipayung, A.; Sudharto, P. A decade of biological control against Chromolaena odorata at the Indonesian Oil Palm Research Institute in Marihat. In Proceedings of the Fifth International Workshop on Biological Control and Management of Chromolaena odorata, Durban, South Africa, 23-25 October 2000; Zachariades, C., Muniappan, R., Strathie, L.W., Eds.; ARC-PPRI: Durban, South Africa, 2002; pp. 46-52.

12. Tjitrosemito, S. Integrated management of Chromolaena odorata: Emphasizing the classical biological control. Biotropia 1998, 11, 9-21.

13. McFadyen, R.E.C.; Desmier de Chenon, R.D.; Sipayung, A. Biology and host specificity of the chromolaena stem gall fly, Cecidochares connexa (Macquart) (Diptera: Tephritidae). Aust. J. Entomol. 2003, 42, $294-297$. [CrossRef]

14. Rizali, A.; Hadi, M.S.; Pudjianto, P.; Buchori, D. A new trophic interaction between invasive weed, its biological control agent, and local insects: A case study of Chromolaena odorata. Biodiversitas 2019, 20, 1006-1011. [CrossRef]

15. Pearson, D.E.; Callaway, R.M. Indirect effects of host-specific biological control agents. Trends Ecol. Evol. 2003, 18, 456-461. [CrossRef]

16. Bellows, T.S. Restoring population balance through natural enemy introductions. Biol. Control 2001, 21, 199-205. [CrossRef]

17. Lonsdale, W.M.; Briese, D.T.; Cullen, J.M. Risk analysis and weed biological control. In Evaluating Indirect Ecological Effects of Biological Control; Wajnberg, E., Scott, J.K., Quimby, P.C., Eds.; CABI Publishing: Wallingford, CT, USA, 2001; pp. 185-210.

18. Simberloff, D.; Stiling, P. How risky is biological control? Ecology 1996, 77, 1965-1974. [CrossRef]

19. Aigbedion-Atalor, P.O.; Adom, M.; Day, M.D.; Uyi, O.; Egbon, I.N.; Idemudia, I.; Igbinosa, I.B.; Paterson, I.D.; Braimah, H.; Wilson, D.D.; et al. Eight decades of invasion by Chromolaena odorata (Asteraceae) and its biological control in West Africa: The story so far. Biocontrol Sci. Technol. 2019, 29, 1215-1233. [CrossRef]

20. Carino, F.O.; Kenmore, P.E.; Dyck, V.A. The FARMCOP suction sampler for hoppers and predators in flooded rice fields. IRRN 1979, 4, 21-22.

21. Borror, D.; Triplehorn, C.H.; Johnson, N.F. An Introduction to the Study of Insects, 6th ed.; Saunders College Publishing: Philadelphia, PA, USA, 1996.

22. CSIRO. The Insects of Australia, 2nd ed.; Melbourne University Press: Melbourne, Australia, 1996. 
23. McAlpine, J.F. Manual of Nearctic Diptera Volume 2; Research Branch Agriculture Canada: Ottawa, ON, Canada, 1987.

24. Goulet, H.; Huber, J.T. Hymenoptera of the World: An. Identification Guide to Families; Canada Communication Group Publishing: Ottawa, ON, Canada, 1993.

25. Bolton, B. Identification Guide to the Ant Genera of the World; Harvard University Press: Cambridge, UK, 1994; p. 222.

26. Colwell, R.K.; Coddington, J.A. Estimating terrestrial biodiversity through extrapolation. Philos. Trans. R. Soc. B Biol. Sci. 1994, 345, 101-118.

27. Clarke, K.R. Non-parametric multivariate analysis of changes in community structure. Aust. J. Ecol. 1993, 18, 117-143. [CrossRef]

28. Legendre, P.; Legendre, L. Numerical Ecology, 2nd ed.; Elsevier: Dordrecht, The Netherlands, 1998.

29. R Core Team. R: A Language and Environment for Statistical Computing; R Foundation for Statistical Computing: Vienna, Austria, 2018.

30. Kindt, R.; Coe, R. Tree Diversity Analysis: A Manual and Software for Common Statistical Methods for Ecological and Biodiversity Studies; World Agroforestry Centre (ICRAF): Nairobi, Kenya, 2005.

31. Wickham, H. Ggplot2: Elegant Graphics for Data Analysis; Springer: New York, NY, USA, 2016.

32. Oksanen, J.; Blanchet, F.G.; Friendly, M.; Kindt, R.; Legendre, P.; McGlinn, D.; Minchin, P.R.; O’Hara, R.B.; Simpson, G.L.; Solymos, P.; et al. Vegan: Community Ecology Package. R Package Version 2.5-3. 2018.

33. Cruttwell, R.E. Insects and mites attacking Eupatorium odoratum in the neotropics: An annotated list of the insects and mites recorded from Eupatorium odoratum L., with a key to the types of damage found in Trinidad. Tech. Bull. Commonw. Inst. Biol. Control 1974, 17, 87-125.

34. Hokkanen, H.M.T.; Pimentel, D. New associations in biological control: Theory and practice. Can. Entomol. 1989, 121, 829-840. [CrossRef]

35. La Salle, J.; Ramadan, M.; Kumashiro, B.R. A new parasitoid of the Erythrina Gall Wasp, Quadrastichus erythrinae Kim (Hymenoptera: Eulophidae). Zootaxa 2009, 2083, 19-26. [CrossRef]

36. Kim, I.-K.; Mendel, Z.; Protasov, A.; Blumberg, D.; La Salle, J. Taxonomy, biology, and efficacy of two Australian parasitoids of the eucalyptus gall wasp, Leptocybe invasa Fisher \& La Salle (Hymenoptera: Eulophidae: Tetrastichinae). Zootaxa 2008, 1910, 1-20.

37. MacGowan, I.; Merz, B.; Wermelinger, B. Six species of Lonchaea Fallén (Diptera, Lonchaeidae) new to Switzerland. Bull. De La Société Entomol. Suisse 2007, 80, 31-35.

38. Watanabe, S.; Murakami, Y.; Hasegawa, E. Effects of aphid parasitism on host plant fitness in an aphid-host relationship. PLoS ONE 2018, 13, e0202411. [CrossRef]

39. Aigbedion-Atalor, P.O.; Day, M.D.; Idemudia, I.; Wilson, D.D.; Paterson, I.D. With or without you: Stem-galling of a tephritid fly reduces the vegetative and reproductive performance of the invasive plant Chromolaena odorata (Asteraceae) both alone and in combination with another agent. BioControl 2018, 64, 103-114. [CrossRef]

40. Aigbedion-Atalor, P.O.; Idemudia, I.; Adom, M.; Day, M. First record of a specialist folivore of Chromolaena odorata (Asteraceae) in Togo, and indices of its range expansion in Nigeria: Implications for biological control. Biocontrol Sci. Technol. 2018, 28, 805-810. [CrossRef]

41. McFadyen, R.E.C. The ecology of Chromolaena odorata in the neotropics. In Proceedings of the Second International Workshop on Biological Control of Chromolaena Odorata, Bogor, Indonesia, 4-8 February 1991; Muniappan, R., Ferrar, P., Eds.; BIOTROP Special Publication: Bogor, Indonesia, 1991; Volume 44, pp. 1-9.

42. McFadyen, R.E.C. Siam weed: A new threat to Australia's north. Plant. Prot. Q. 1989, 4, 3-7.

43. Wolda, H. Altitude, habitat and tropical insect diversity. Biol. J. Linn. Soc. 1987, 39, 313-323. [CrossRef]

44. McCoy, E.D. The distribution of insects along elevational gradients. Oikos 1990, 58, 313-322. [CrossRef]

45. Day, M.D.; Riding, N.; Senaratne, K.A.D.W. The host specificity and climatic suitability of the gall flyCecidochares connexa(Diptera: Tephritidae), a potential biological control agent forChromolaena odorata(Asteraceae) in Australia. Biocontrol Sci. Technol. 2016, 26, 691-706. [CrossRef]

46. Aigbedion-Atalor, P.O.; Idemudia, I.; Witt, A.B.R.; Day, M.D. First record of the impact of the parasitism of Cecidochares connexa (Diptera: Tephritidae) by a solitary larval ectoparasitoid in West Africa: Cause for concern? J. Plant. Dis. Prot. 2018, 126, 93-95. [CrossRef] 
47. Van Driesche, R.; Hoddle, M. Non-target effects of insect biocontrol agents and trends in host specificity since 1985. CAB Rev. 2016, 11, 1-66. [CrossRef]

48. Hopper, K.R. Research needs concerning non-target impacts of biological control introductions. In Evaluating Indirect Ecological Effects of Biological Control; Wajnberg, E., Scott, J.K., Quimby, P.C., Eds.; CABI Publishing: Wallingford, CT, USA, 2001; pp. 39-56.

(C) 2020 by the authors. Licensee MDPI, Basel, Switzerland. This article is an open access article distributed under the terms and conditions of the Creative Commons Attribution (CC BY) license (http://creativecommons.org/licenses/by/4.0/). 